\title{
Phytochemical Profiling and Anti-cancer Study of Lyophilized Pure Fruit Juice of Citrus Limon (L.) Osbeck against Human Breast Cancer (MCF-7) Cell Line
}

\author{
Saranya. A., *Sivakumari. K., Ashok. K. and Rajesh. S \\ PG and Research Department of Zoology Presidency College (Autonomous) Chennai-5 \\ *Associate Professor of Zoology, Presidency College, Chennai. \\ *Email: dr.sivakumari@rediffmail.com
}

\begin{abstract}
The present study aims at the phytochemical profiling of lyophilized pure fruit juice powder of Citrus limon and demonstrates its efficacy as an antitumor agent against human breast cancer cell line (MCF-7). The cytotoxicity was evaluated using the changes in cell morphology, cell viability, and DNA fragmentation, the percentage of cell viability was determined by MTT assay. Our results showed that lyophilized pure fruit juice powder of Citrus limon inhibited the proliferation of human breast cancer cell line MCF-7 with an $\mathrm{IC}_{50} 98.16 \mu \mathrm{g} / \mathrm{ml}$ at $48 \mathrm{~h}$ incubation, it was shown to promote apoptosis as seen as DNA fragmentation using ladder assay. These results suggest that lyophilized pure fruit juice powder of Citrus limon has antiproliferative effect against MCF-7 cell by suppressing its growth.
\end{abstract}

Key words: Citrus limon fruits, FT-IR, GC-MS, MTT, DNA fragmentation.

\section{Introduction}

Cancer is a multi-factorial, multi-faceted, and multi-mechanistic disease requiring a multi-dimensional approach for its treatment, control, and prevention. Cancer remains a major public health burden in developed as well as developing countries [1-4]. Cancer as a second cause of death after heart disease in the world has posed a great challenge to the field of medicine and immunology [5]. WHO has predicted that the number of new cases of cancer may increase up to 15 million in the year 2020 [6]. Cancer is a group of diseases that cause cells in the body to change and grow out of control. Most types of cancer cells eventually form a lump or mass called a tumor, and are named after the part of the body where the tumor originates [7].

Human breast cancer is the most commonly occurring cancer in females, rare in male. It accounts for $23 \%$ of newly occurring cancer worldwide and represents $13.7 \%$ of all cancer death. In both developed and developing countries, breast cancer is the most frequent cancer and most frequent cause of cancer deaths [8]. It's a serious global health problem being the second most common of all cancers and by far the most frequent cancer amongst women [9]. Although breast cancer is considered as one of the most chemo sensitive solid tumors, most initially responsive tumors relapse and develop resistance to a broad spectrum of drugs. Consequently, breast cancer becomes refractory to cytotoxic drugs and is typically incurable [10]. The vast majority of breast cancers begin in the parts of the breast tissue that are made up of glands for milk production, called lobules, and ducts that connect the lobules to the nipple. The remainder of the breast is made up of fatty, connective, and lymphatic tissues [7].

Chemotherapy is one of the commonly used strategies in breast cancer treatment. This therapy is usually associated with adverse side effects, ranging from nausea to bone marrow failure [11] and development of multi-drug resistance (MDR) [12]. The toxicity and resistance of traditional chemotherapeutic drugs makes it critical to develop new targets and novel drugs for cancer therapy. Despite extensive research and rapid progress in cancer treatment, there is a growing demand for new therapies. It is important to identify new agents and targets for the treatment of cancer $[13,14]$.

More than $60 \%$ of the chemotherapeutic drugs are developed from plants and their derivatives. Medicinal plants are potential sources of natural products exhibiting anti-proliferation and antimetastatic properties [15]. In addition to synthetic drugs, immense use of natural products and its derivatives in the development of anti-cancer drugs are increasing all over the world because of lesser 
side effects as compared to synthetic drugs [16-27]. In search of new agents to treat cancer with fewer or less side effects, a number of medicinal plants have been evaluated [28-35]. More than 50\% of all modern drugs in clinical use are of natural products, many of which have been recognized to have the ability to include apoptosis in various cancer cells of human originals; there is an urgent need to develop much effective and less toxic drugs [36,37].

Citrus one of the important economically plants, but attention leaves and seeds the role of citrus not given importance in comparison to fruits despite the presence of phenols quantity that varies among species [38]. Majority of citrus fruits are preferably eaten fresh e.g., oranges, mandarins, grapefruits, Clementines, and tangerines. Orange and grapefruit produce very palatable juice and hence are used to make nutritious and popular breakfast [39]. Lemon is an important medicinal plant of the family Rutaceae. It is cultivated mainly for its alkaloids, which are having anti-cancer activities [40]. Its fruits have peculiar fragrance partly due to flavonoids and limonoids present in the peel and these fruits are good sources of vitamin $\mathrm{C}$ and flavonoids [41].

Lemons and limes can be used to make lemonades and pickles and their juices can be added to various food preparations as flavoring agents. Citrus fruits are rich sources of active compounds and beneficial for human health e.g., vitamin $\mathrm{C}$, carotenoids, flavonoids, limonoids, essential oils, acridone alkaloids, minerals, and vitamin B complex [42]. Flavonoids especially polymethoxyflavones, flavanone glycosides, and limonoids are natural secondary metabolite compounds of citrus [43]. Fruits have a lot of biological effective compounds, that have the ability to attack radical free and work as anti-natural oxidative stress, such as phenolic compounds (phenolic acids, flavonoids, and tannins) make them play an important role in reducing the risk of many diseases like cancers, cardiovascular and neurological diseases [44].

Therefore, the present investigation was aimed to analyze the phyto-constituents present in lyophilized fruit juice powder of Citrus limon and its anti-cancer and anti-apoptotic activity against human breast cancer (MCF-7) cell line.

\section{Materials and Methods}

\subsection{Collection and Identification of Fruit}

Fresh lemon fruits (Scientific name) were collected from Ammoor village, Vellore District, Tamil Nadu, India, and authentically identified as C. limon (L.) Osbeck, by Dr. P.T. Devarajan, Associate Professor of Plant Biology and Plant Biotechnology, Presidency College, Chennai-05.

\subsection{Preparation of Pure Fruit Juice Powder}

Fresh fruits were washed and the pure juice was taken from the fruit by squeezing them. The pure juice was filtered using Whatmann No.1 filter paper and the filtrate was lyophilized by subjecting it to freeze dryer. The yield of lyophilized powder was quantified and further subjected to biological activity.

\subsection{Qualitative Phytochemical Analysis}

Pure lyophilized juice powder of lemon fruit was subjected to preliminary phytochemical screening for its phytoconstituents according to Kokate (1988) method [45].

\section{$2.4 \quad$ FT-IR Spectral Analysis}

Lyophilized fruit juice powder was used for FT-IR analysis. Precisely, $10 \mathrm{mg}$ of the dried powder was encapsulated in $100 \mathrm{mg}$ of $\mathrm{KBr}$ pellet, in order to prepare translucent sample discs. The powdered samples were loaded in FT-IR spectroscope (Shimadzu, IR Affinity 1, Japan), with a scan range from 4000 to $400 \mathrm{~cm}^{-1}$ with a resolution of $4 \mathrm{~cm}^{-1}$. The output of the results in the form of graphs, was analyzed and the functional groups were identified by the peaks and the reference tables. 


\section{$2.5 \quad$ GC-MS Spectral Analysis}

GC-MS spectral analysis was carried out to determine the presence of aromatic compounds in the powders. The model of the GC-MS used for mass spectral identification was an Agilent 7890 interfaced to a 240 mass selective detector with ion trap. The capillary column $(30 \mathrm{~m} \times 0.25 \mathrm{~mm} \times 0.25 \mu \mathrm{m}$ film thickness) was HP-5MS. The oven temperature was initially maintained at $80^{\circ} \mathrm{C}$ and then increased to $300^{\circ} \mathrm{C}$. The carrier gas used was nitrogen $(99.999 \%$ ), at a flow rate of $1.0 \mathrm{ml} / \mathrm{min}$., and injection volume of $1.0 \mu \mathrm{L}$ was employed (split ratio of 10:1). The electron-impact ionization of the mass spectrometry was operated at electron energy of $70 \mathrm{eV}$. Mass spectra were taken at $70 \mathrm{eV}$, a scan interval of 0.5 seconds and fragments from 40 to 450 Da. Total GC running time was 61 min.

\subsection{Cell Viability Assay (MTT Assay)}

Cell viability was assessed by the MTT method as described by Mosmann (1983) [46].

\subsection{Cell Morphological Study}

The morphological changes of pure juice powder-treated MCF-7 cell lines were assessed by using light microscopy. Cancer cells $\left(1 \times 10^{6} \mathrm{cells} / \mathrm{ml}\right)$ were plated in $100 \mathrm{~mm}$ dishes and incubated for $24 \mathrm{~h}$ under controlled environment. Then, the spent medium was removed, followed by addition of fresh medium with or without juice powder at an inhibitory concentration and incubated for $48 \mathrm{~h}$. After incubation, the cells were visualized under Radical inverted light microscope at 20X magnification.

\subsection{DNA Fragmentation Assay}

Low molecular weight genomic DNA was powdered using the previously described method of Yawata (1998) [47].

\subsection{Statistical Analysis}

The data of MTT assay with five replicates were subjected to statistical analysis and the mean value along with its respective standard error was calculated. The per cent change between control and experimental data was calculated. The data were analyzed statistically using Analysis of Variance (ANOVA). The data together with tables and graphs/bar diagrams are presented in appropriate places in the text.

\section{$3 \quad$ Results}

Lyophilized fresh pure juice of $C$. limon L. was dark brown in color and had powder texture which was used for the further studies.

\subsection{Qualitative Phytochemical Analysis}

The preliminary phytochemical analysis of lyophilized pure fruit juice powder of $C$. limon showed the presence of alkaloids, tannins, and proteins in trace amount, and the phenols, flavonoids, and acids in high amount (Table. 1).

Table 1. Phytochemical screening of lyophilized powder of C. limon

\begin{tabular}{c|c}
\hline Primary Phytochemicals & Presence/Absence \\
\hline Alkaloids & + \\
\hline Anthraquinones & - \\
\hline Carbohydrates & - \\
\hline Flavonoids & +++ \\
\hline
\end{tabular}




\begin{tabular}{c|c}
\hline Glycosides & - \\
\hline Phenols & +++ \\
\hline Quinones & - \\
\hline Saponins & - \\
\hline Tannins & + \\
\hline Triterpenoids & - \\
\hline Steroids and Phytosteroids & - \\
\hline Proteins & + \\
\hline Acids & +++ \\
\hline Note: +++- Highly present; + - Trace; - Absent
\end{tabular}

\section{$3.2 \quad$ FT-IR Spectral Analysis}

The FT-IR spectrum was used to identify the functional group of the active components based on the peak value in the region of infrared radiation. The results of FT-IR peak values and functional groups were presented in Table 2 and Figure 1. The lyophilized lemon juice powder revealed the presence of alkyl halides, amines, carboxylic acids, phenols, and alcohols.

Table 2. FT-IR spectral peak values and functional groups (4000 to $400 \mathrm{~cm}-1$ ) obtained lyophilized powder of C. limon

\begin{tabular}{|c|c|c|c|c|}
\hline S. No. & Peak cm ${ }^{-1}$ & Intensity & Peak Area & Functional Group \\
\hline 1 & 401.19 & 0.3 & 13.316 & \multirow{5}{*}{ Alkyl halides (R-I) C-I stretch } \\
\hline 2 & 412.77 & 0.09 & 29.59 & \\
\hline 3 & 430.13 & 0.079 & 27.701 & \\
\hline 4 & 435.91 & 0.206 & 19.491 & \\
\hline 5 & 453.27 & 0.067 & 15.343 & \\
\hline 6 & 462.92 & 0.138 & 14.235 & \multirow{5}{*}{$\begin{array}{l}\text { Alkyl halides }(\mathrm{R}-\mathrm{Br}) \\
\text { C-Br stretch }\end{array}$} \\
\hline 7 & 474.49 & 0.162 & 23.862 & \\
\hline 8 & 487.99 & 0.105 & 20.959 & \\
\hline 9 & 499.56 & 0.122 & 27.067 & \\
\hline 10 & 507.28 & 0.047 & 32.717 & \\
\hline 11 & 520.78 & 0.16 & 20.363 & \multirow{9}{*}{$\begin{array}{c}\text { Amines }\left(\mathrm{R}-\mathrm{NH}_{2}\right) \\
\text { Intensity }(\mathrm{w}-\mathrm{m}) \mathrm{N}-\mathrm{H} \text { bond }\end{array}$} \\
\hline 12 & 530.42 & 0.15 & 33.632 & \\
\hline 13 & 547.78 & 0.489 & 34.162 & \\
\hline 14 & 574.79 & 0.883 & 31.219 & \\
\hline 15 & 590.22 & 1.087 & 26.153 & \\
\hline 16 & 621.08 & 1.368 & 28.236 & \\
\hline 17 & 667.37 & 1.713 & 16.88 & \\
\hline 18 & 680.87 & 1.829 & 16.667 & \\
\hline 19 & 1608.63 & 1.809 & 52.177 & \\
\hline 20 & 1645.28 & 1.329 & 14.296 & \multirow{2}{*}{$\begin{array}{c}\text { Carboxylic acids } \\
\text { Intensity ( } \mathrm{S} \text { broad) } \\
\text { O-H stretch }\end{array}$} \\
\hline 21 & 2692.63 & 1.977 & 19.677 & \\
\hline 22 & 2742.78 & 1.822 & 79.69 & \multirow{7}{*}{$\begin{array}{c}\text { Carboxylic acids } \\
\text { Intensity ( } \mathrm{S} \text { broad) } \\
\text { O-H stretch }\end{array}$} \\
\hline 23 & 2769.78 & 1.732 & 47.249 & \\
\hline 24 & 2802.57 & 1.624 & 51.326 & \\
\hline 25 & 2846.93 & 1.409 & 80.7 & \\
\hline 26 & 2872.01 & 1.334 & 39.533 & \\
\hline 27 & 2891.3 & 1.26 & 40.039 & \\
\hline 28 & 2902.87 & 1.234 & 18.35 & \\
\hline
\end{tabular}




\begin{tabular}{|c|c|c|c|c|}
\hline S. No. & Peak cm-1 & Intensity & Peak Area & Functional Group \\
\hline 29 & 2916.37 & 1.168 & 25.933 & \\
\hline 30 & 2937.59 & 1.159 & 22.369 & \multirow{6}{*}{ Functional Group } \\
\hline 31 & 2949.16 & 1.151 & 22.389 & \\
\hline 32 & 2964.59 & 1.156 & 22.391 & \\
\hline 33 & 2995.45 & 1.137 & 22.437 & \\
\hline 34 & 3018.6 & 1.112 & 26.304 & \\
\hline 35 & 3039.81 & 1.073 & 26.55 & \\
\hline 36 & 3061.03 & 1.047 & 22.832 & $\begin{array}{c}\text { Carboxylic acids } \\
\text { Intensity ( } \mathrm{S} \text { broad }) \\
\mathrm{O}-\mathrm{H} \text { stretch }\end{array}$ \\
\hline 37 & 3091.89 & 0.996 & 23.108 & \multirow{20}{*}{$\begin{array}{c}\text { Phenols and alcohols } \\
\text { Hydrogen-bonded O-H } \\
\text { Stretch }\end{array}$} \\
\hline 38 & 3105.39 & 0.967 & 23.245 & \\
\hline 39 & 3120.82 & 0.92 & 35.106 & \\
\hline 40 & 3134.33 & 0.93 & 11.739 & \\
\hline 41 & 3149.76 & 0.88 & 23.696 & \\
\hline 42 & 3169.04 & 0.846 & 31.761 & \\
\hline 43 & 3196.05 & 0.795 & 28.142 & \\
\hline 44 & 3207.62 & 0.778 & 24.346 & \\
\hline 45 & 3228.84 & 0.727 & 24.622 & \\
\hline 46 & 3242.34 & 0.736 & 20.889 & \\
\hline 47 & 3261.63 & 0.721 & 20.619 & \\
\hline 48 & 3275.13 & 0.693 & 24.831 & \\
\hline 49 & 3296.35 & 0.667 & 20.889 & \\
\hline 50 & 3305.99 & 0.648 & 21.03 & \\
\hline 51 & 3327.21 & 0.611 & 46.61 & \\
\hline 52 & 3354.21 & 0.611 & 25.565 & \\
\hline 53 & 3375.43 & 0.605 & 21.32 & \\
\hline 54 & 3402.43 & 0.585 & 25.795 & \\
\hline 55 & 3429.43 & 0.596 & 25.684 & \\
\hline 56 & 3626.17 & 1.504 & 34.093 & \\
\hline
\end{tabular}

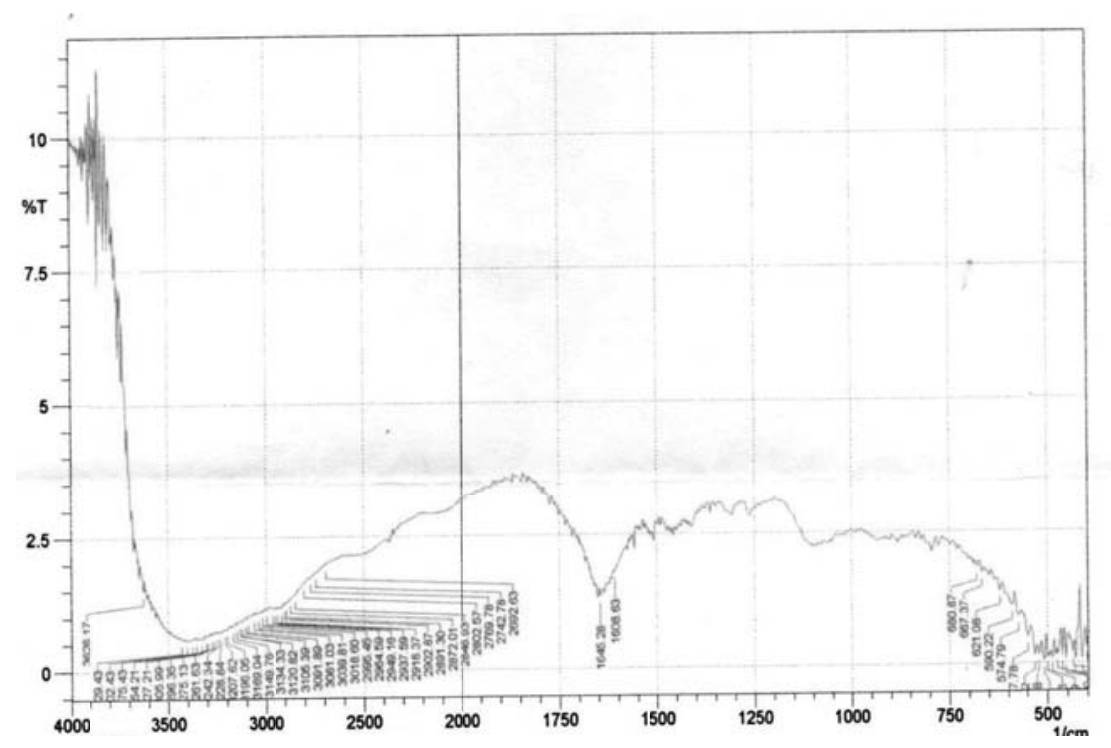

Figure 1. FT-IR spectra of various functional groups (4000 to $400 \mathrm{~cm}^{-1}$ ) obtained for lyophilized powder of $C$. limon 


\subsection{GC-MS Spectral Analysis}

GC-MS spectra of lyophilized powder of $C$. limon contain three active compounds such as 1,3-Dioxane2-propanol, 2-methyl (RT-1.98), Methyl-hexadecyl ether (RT-19.92), D asicarpidan-1-methanol, acetate (ester) (RT-29.87). The peaks are given in Figure 2 and the individual mass peak and NIST match are given in Figure 3a to 3c.

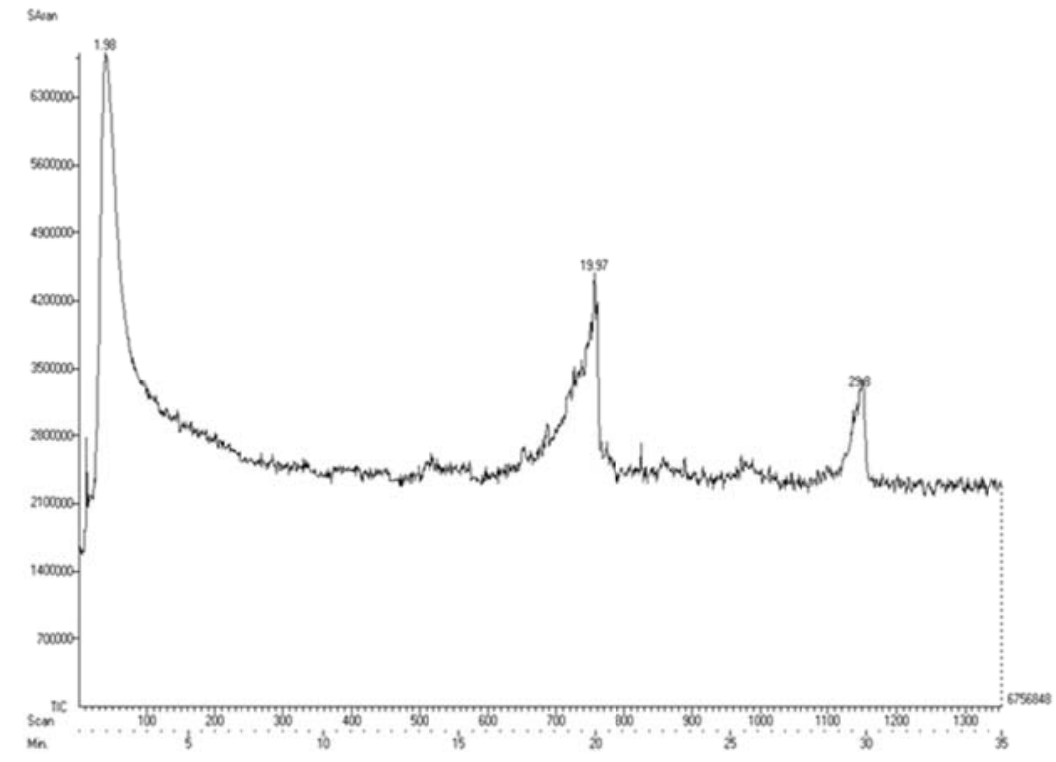

Figure 2: GC-MS chromatogram of C. limon lyophilized powder

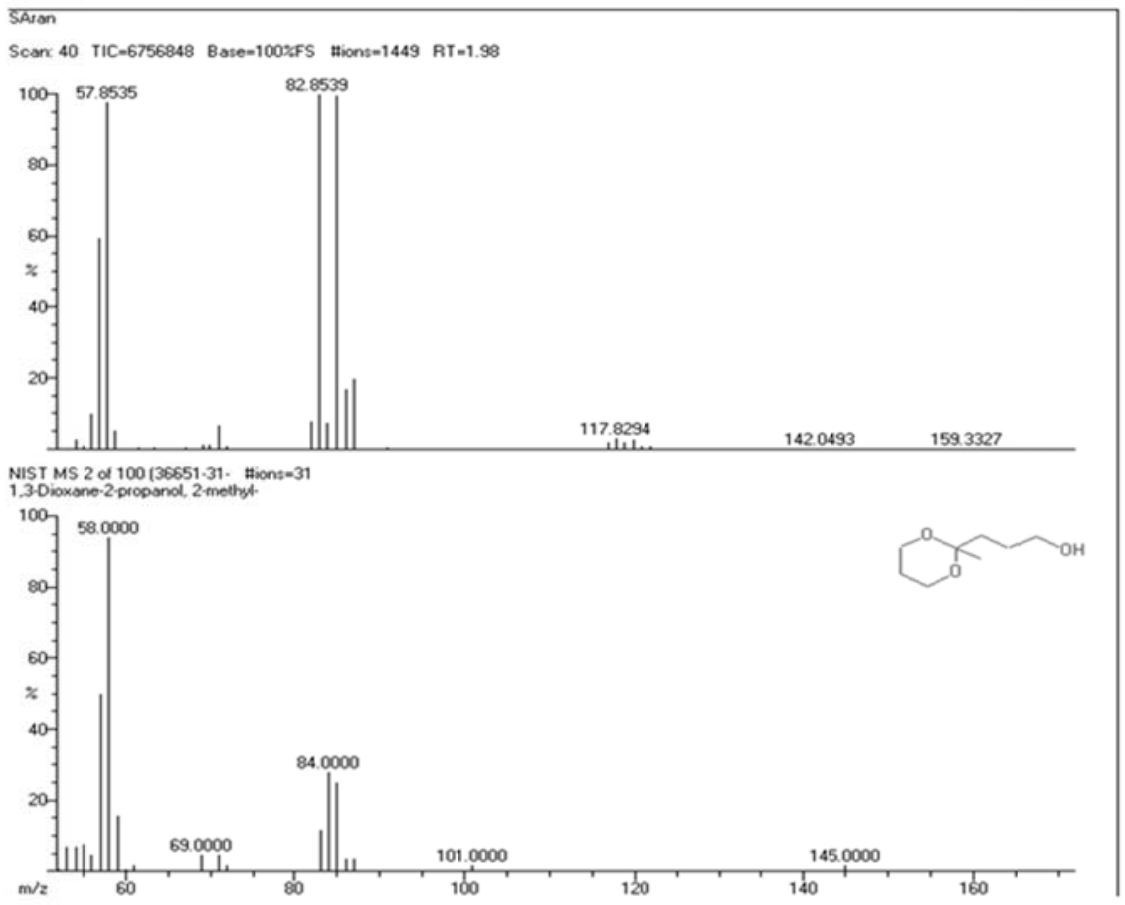

Figure 3a. Mass peak of RT 1.98 


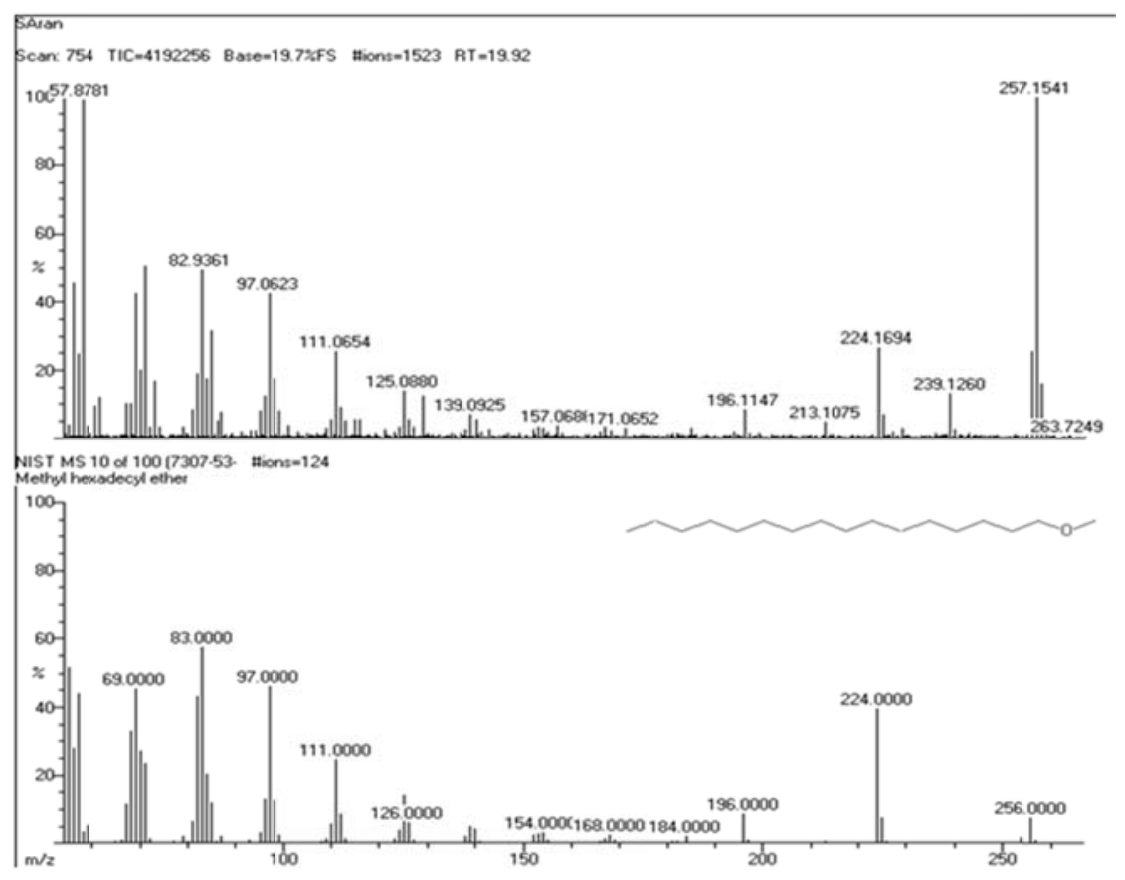

Figure 3b. Mass peak of RT 19.92

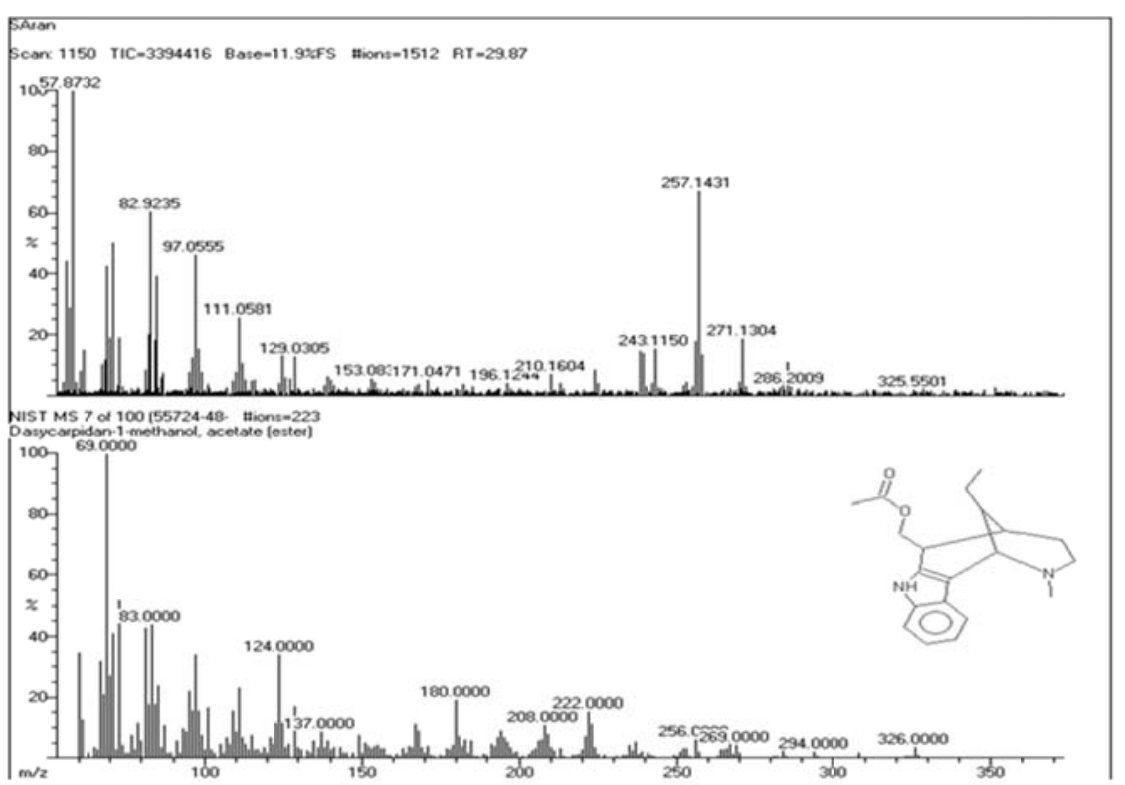

Figure 3c. Mass peak of RT 29.87

\subsection{MTT Assay}

Anti-proliferation of the cells was assessed by MTT assay for $48 \mathrm{~h}$ in the lemon juice powder and the data are presented in Table 3. The data revealed that anti-proliferative activity was seen in the MCF-7 cells when treated with different concentrations of fruit juice powder; the cell anti-proliferation being directly proportional to concentration. Statistical treatment of the data by two-way ANOVA showed that all the values were significant at $5 \%$ level. Per cent cell viability of MCF 7 cells was assessed for 48 $\mathrm{h}$ in the pure fruit juice powder at varying concentrations. The control cells were $100 \%$ viable and the viability decreased significantly with increase in concentration of the fruit juice powder. The per cent 
decrease in cell viability was indirectly proportional to the concentration of $C$. limon powder. ANOVA analysis revealed that all the values were significantly different.

Table 3. Per cent cell viability of MCF-7 cells for $48 \mathrm{~h}$ when treated with pure fruit juice powder of C. limon.

\begin{tabular}{c|c|}
\hline Concentration of lyophilized fruit juice powder & Percentage of cell viability \\
\hline Control & 100 \\
\hline $25 \mu \mathrm{g} / \mathrm{ml}$ & $\begin{array}{c}92.45 \pm 0.25^{*} \\
(-7.55)\end{array}$ \\
\hline $50 \mu \mathrm{g} / \mathrm{ml}$ & $\begin{array}{c}78.29 \pm 0.41^{*} \\
(-21.71)\end{array}$ \\
\multirow{2}{*}{$75 \mu \mathrm{g} / \mathrm{ml}$} & $\begin{array}{c}63.57 \pm 0.42^{*} \\
(-36.43)\end{array}$ \\
\hline $100 \mu \mathrm{g} / \mathrm{ml}$ & $\begin{array}{c}48.92 \pm 0.44^{*} \\
(-51.08)\end{array}$ \\
\hline \multirow{2}{*}{$150 \mu \mathrm{g} / \mathrm{ml}$} & $\begin{array}{c}39.27 \pm 0.97^{*} \\
(-60.73)\end{array}$ \\
\hline
\end{tabular}

Values are mean + S.E. of five individual observations.

Values in parentheses are per cent change over control.

- Denotes per cent decrease over control.

* Denotes that values are significant at $\mathrm{P}<0.05$.

At $100 \mu \mathrm{g} / \mathrm{ml}$ concentration of the lyophilized powder of C. limon, at the end of $48 \mathrm{~h},-51.08 \%$ viability of the cells was observed. The median inhibiting concentration $\left(\mathrm{IC}_{50}\right)$ value was $98.16 \mu \mathrm{g} / \mathrm{ml}$, where $50 \%$ of the cells were viable. From the results it is pragmatic that pure lemon fruit juice powder has profound effect in controlling MCF-7 cell proliferation. The data altogether depict that the C. limon lyophilized powder significantly controls cell proliferation of MCF-7 cells even at low concentrations. The graphical data are presented in Figure 4.

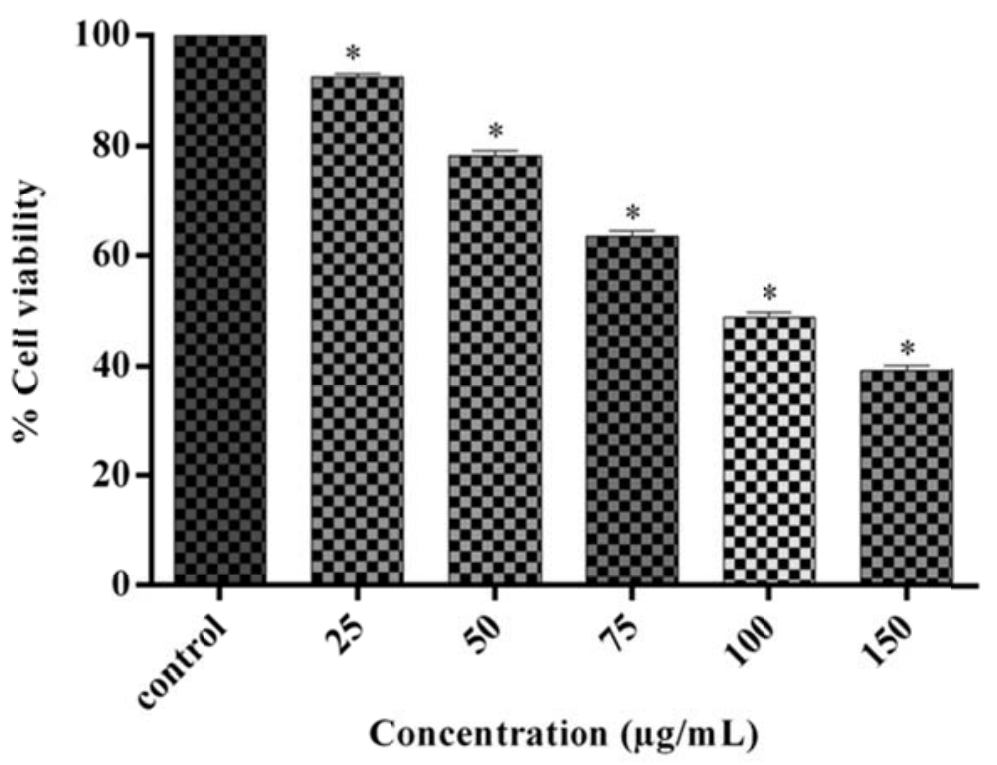

Figure 4. Bar diagram showing decrease in per cent viability of MCF-7 cells for $48 \mathrm{~h}$ when treated with pure fruit juice powder of C. limon. 


\subsection{Cell Morphological Studies}

For morphological observations, MCF-7 cells were photographed in 10X magnification. The control cells showed irregular and confluent aggregates with rounded and polygonal cell morphology. But in the cells treated with pure $C$. limon fruit juice powder, after $48 \mathrm{~h}$ of incubation, the appearance of polygonal cells began to shrink and became spherical in shape (Figure 5) and the cell shrinkage increased progressively; the increase being dose and time dependent.

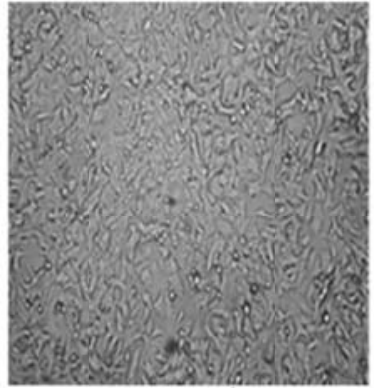

Control

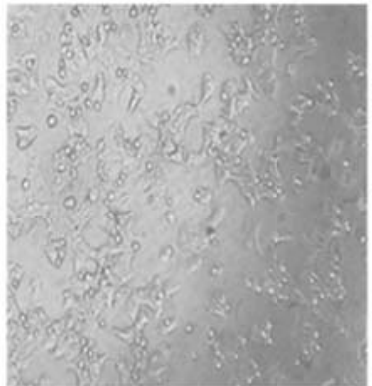

IC50

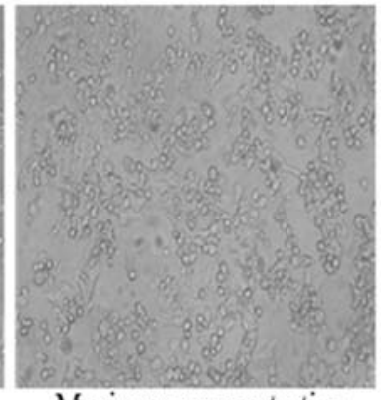

Maximum concentration

Figure 5. Morphological changes induced by MCF-7 cells induced by lyophilized powder of C. limon.

\subsection{DNA Fragmentation Study}

The lyophilized powder at $100 \mathrm{\mu g} / \mathrm{ml}$ concentration showed the induced DNA fragmentation. The fragments were observed from $500 \mathrm{bp}$ to $600 \mathrm{bp}$, which indicate that MCF-7 cellsi underwent apoptosis by the induction of lyophilized powder (Figure 6).

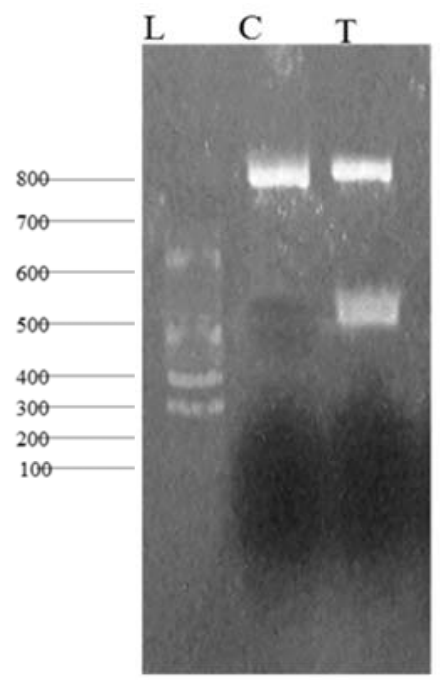

\author{
L: $1 \mathrm{~kb}$ DNA Ladder \\ C: Control Cell \\ T: Treated with $100 \mu \mathrm{g} / \mathrm{ml} 48 \mathrm{~h}$ \\ incubation
}

Figure 6. DNA fragmentation in MCF-7 cells induced by lyophilized powder of C. limon.

\section{Discussion}

According to Merina et al. (2012) [48], in recent times, medicinal plants occupy an important position for being the paramount sources of drug discovery, irrespective of its categorized groups such as herb, shrub, or tree. Plants have been indispensable in treating diverse forms of diseases including cancer. Natural products are formulated to generate different types of effective drugs to enhance anti-cancer activities. Proper understanding of the complex synergistic interaction of various constituents of anti- 
cancer herbs, would help in formulating the design to attack the cancerous cells without harming the normal cells of the body as proved by the works of [49-67].

Among other herbal products, citrus fruits have been collected and used by man for centuries for medicinal, herbal, and agricultural purposes [68]. In citrus fruits, the lemon fruit C. limon is used in Siddha practice for curing giddiness, vomiting, nausea, thirst, scurvy, and in febrile and inflammatory conditions. Externally it is useful in whitlow, the juice of the fruit with sugar cures excessive thirst, it is processed into various forms and when taken for 6 months, helps in curing ascites, lethargy, expression and also helps in removing grey hair, and thus it acts as an elixir, coral prepared as white calyx is given with the adjuvant of lime juice helps in curing chronic and excessive diarrhea and dysentery [69]. Keeping this in mind, this study was planned to explore the phytochemical constituents of C. limon and also to anti-cancer potential against MCF-7 breast cancer cell line.

Phytochemicals are already a part of our diet through vegetables and fruits. Citrus fruits are found to be rich in phytoconstituents [70, 71]. Citrus flavonoids have a large spectrum of biological including anti-bacterial, anti-fungal, anti-diabetic, anti-cancer, and anti-viral activities [72,73]. Orange peel is medically used against fungi [74]. Limonene present in Citrus sinensis (sweet orange) is known as a significant chemo preventive agent with potential value as a dietary anti-cancer tool in humans $[75,76]$. The peel of Citrus fruits is a rich source of flavonoids glycosides, coumarins, $\beta$ and $\gamma$-sitosterol, glycosides, and volatile oils as reported by Shahnah et al. (2007) [77]. Many polymethoxylated flavones have several important bioactivities, which are very rare in other plants as stated by Ahmad et al. (2006) [78]. In addition, the fiber of citrus fruit also contains bioactive compounds, such as polyphenols, the most important being vitamin C (Ascorbic acid), and they certainly prevent and cure vitamin C deficiency-the cause of scurvy [79].

The importance of natural bioactive compounds has led to the development of a large and potential market for natural sources in pharmaceutics and food products, polyphenols in the plants are considered to be free natural radical defenses that were acknowledged to be beneficial for human health as an antioxidant, anti-tumor, and anti-microbial agent as reported [80.81]. C. limon (lemon) is also a vital medicinal plant of family Rutaceae. It is cultivated chiefly for its alkaloids contents, which are having anti-cancer activities, its peel show strong anti-microbial activity as reported by Dhanavade et al. (2011) [40]. Many studies have been reported on the anti-microbial and anti-oxidant effect of edible part as well as non-edible part of citrus fruits [35].

Therefore, the present study was undertaken to determine the anti-cancer effect of C. limon lyophilized pure fruit juice powder against human breast cancer (MCF-7) cells. In our study, the lyophilized pure fruit juice powder of $C$. limon caused cell growth inhibition of MCF-7 cells. This might be due to the presence of phytoconstituents such as alkaloids, tannins, phenols, flavonoids, and acids in the lyophilized pure fruit juice powder. Moreover, the presence of functional groups as detected by FTIR study of $C$. limon lyophilized pure fruit juice powder like alkyl halides, amines, carboxylic acids, phenols, and alcohols and the presence of three active compounds such as 1,3-Dioxane-2-propanol 2methyl (RT-1.98), Methyl-hexadecyl ether (RT-19.92), D asicarpidan-1-methanol acetate (ester) (RT29.87) when analyzed by GC-MS spectra of lyophilized pure fruit juice powder of $C$. limon might have also acted either alone or synergistically in combination, thus inhibiting the growth and viability of the MCF-7 cells.

Likewise, morphological analysis of the cells showed shrinkage of MCF-7 cells treated with lyophilized pure fruit juice powder of $C$. limon. This shrinkage may be due to the inhibitory effect of the phytoconstituents and/or functional groups and/or active compounds present in the lyophilized pure fruit juice powder of $C$. limon. The above work finds support from similar observations on the effect of cladribine [82], Antrodia camphorata [19], selenium and vitamin E [83], zoledronic acid [84], doxorubicin [85], metronidazole [86], gemcitabine [87], fruit peel extracts [81], triazole linked N-(pyrimidin-2-yl) banzol [d] thaizol-2-amine [5] on MCF-7 cells.

In our study, in $100 \mu \mathrm{g} / \mathrm{ml}$ concentration of lyophilized pure fruit juice powder of $C$. limon caused $51.08 \%$ viability of $\mathrm{MCF}-7$ cells, at the end of $48 \mathrm{~h}$. The $\mathrm{IC}_{50}$ value of the lyophilized pure fruit juice powder was $98.16 \mathrm{\mu g} / \mathrm{ml}$. In our in vitro studies of MCF-7 cells treated with lyophilized pure fruit juice powder of $C$. limon, the growth inhibitory effects of this pure fruit juice powder prove its anti-cancer effects. Our preliminary studies on major constituents of $C$. limon lyophilized pure fruit juice powder confirm that phytochemicals are important constituents and they possess anti-cancer and anti-apoptotic activity. Similar results were also recorded which were followed by the author [89]. 
DNA fragmentation study in the present investigation showed that the lyophilized pure fruit juice powder of C. limon at $100 \mathrm{\mu g} / \mathrm{mL}$ concentration induced DNA fragmentation. DNA fragment was observed from $500 \mathrm{bp}$ to $600 \mathrm{bp}$, which indicates that MCF-7 cells underwent apoptosis which was induced by the lyophilized pure fruit juice powder. Similar observations were also recorded by Yang et al. (2006) [19] in MCF-7 cell lines, when treated with Antrodia camphorata, a Chinese herbal medicine.

\section{Conclusion}

In conclusion, the lyophilized pure fruit juice powder of $C$. limon fruit demonstrates promising anticancer and anti-apoptotic properties against human breast cancer (MCF-7) cells by in vitro method. Increasing awareness, promotion, and utilization of this fruit for public benefits are highly encouraged and identification of active phytoconstiuents in the juice will serve as a natural cytotoxic agent against various cancers.

\section{References}

1. Alison, MR., (2001). Department of Histopathology and hepatology Imperial college school of medicine London and histopathology unit. Imperial cancer Research Fund. London, UK Liver., 21: 367-73.

2. Jemal, A., Murray, T., Samuels, A., Ghafoor, A., Ward, E. and Thun, M. (2003). Cancer statistics. Cancer J. Clin., 53: 5-26.

3. Balachandran, P. and Govindarajan, R. (2005). Cancer an ayurvedic perspective. Pharmaco. Res., 51: 9-30.

4. Siegel, RL., Miller, KD. and Jemal, A. (2015). Cancer statistics. CA Cancer J. Clin., 65(1): 5-29.

5. Kumbhare, MR., Dadmal, TL., Ramaiah, JM., Kishore, VSK., Valli, P., Tiwari, KM., Appalanaidu, K., Rao, KY. and Bhadra, PM. (2015). Synthesis and anticancer of novel triazole linked N-(pyrimidin-2-yl)benzol[d]thaizol-2amine derivatives as inhibitors of cell survival proteins and inducers of apoptosis in MCF-7 breast cancer cells. Bioorg. Med. Chem. Lett., 25: 654-658.

6. Tavakoli, J., Miar, S., Zadehzare, MM. and Akbari, H. (2012). Evaluation of effectiveness of herbal medication in cancer care: A Review Study. Iran. J. Cancer Prevent., 5(3): 144-56.

7. American Cancer Society. (2015). For written permission, address the Legal department of the American Cancer Society. 250 Williams Street, NW, Atlanta, GA: 30303-1002.

8. Ferlay, JBF., Pisani, P. and Parkin, DM. (2000). GLOBOCAN 2000. Cancer incidence and mortality and prevalence worldwide. Version 1.0. IARC Cancer., 19: 1941-52.

9. Ferlay, J., Shin, HR., Bray, F., Forman, D., Mathers, C. and Parkin, DM. (2010). Estimates of worldwide burden of cancer in 2008: GLOBOCAN 2008. Int. J. Can., 127(12): 2893-2917.

10.Harris, JR., Lippman, ME., Morrow, M. and Osborne, CK. (2000). Treatment of metastatic breast cancer, in: J.R. Harris, M.E. Lippmann, M. Morrow (Eds.), Diseases of the Breast, 2nd ed., Lippincott Williams and Wilkins, Philadelphia, 749.

11.Cancer Research UK. (2013). Side Effects of Cancer Drugs. Available online: http://cancerhelp. cancerresearchuk.org/about cancer treatment cancer drugs side-effects.

12.Raguz, S. and Yague, E. (2008). Resistance to chemotherapy: New treatments and novel insights into an old problem. Br. J. Cancer., 99: 387-391.

13.Jemal, A., Siegel, R., Ward, E., Murray, T., Xu, J. and Thun, MJ. (2007). Cancer Statistics. CA Cancer J. Clin., 57: $43-66$.

14.Anand, P., Kunnumakara, AB., Sundaram, C., Harikumar, KB., Tharakan ST., Lai, OS, Sung, B. and Aggarwal, BB. (2008). Pharm. Res., 25: 2097.

15.Sun, Y., Xun, K., Wang, Y. and Chen, X. (2009). The effects of plant falavonoids on mammalians cells. Anticancer. Drugs., 20: 757-769.

16.Dev, S. (2000). Impact of natural products in modern drug development. Ind. J. Exp. Biol., 48: 191-198.

17.Srivastava, SK., Rai, V., Srivastava, M., Rawat, AKS. and Mehrotra, S. (2000). Estimation of heavy metals in different berberis species and its market samples. Environ. Monit. Assess., 116: 315-320.

18.Newman, DJ., Cragg, GM. and Snader, KM. (2003). Natural products as sources of new drugs over the period. J. Nat. Prod., 66: 1022-1037. 
19.Yang, HL., Chen, CS., Chang, WH., Lu, FJ., Lai, YC. and Chen, CC. (2006). Growth inhibition and induction of apoptosis in MCF-7 Breast cancer cells by Antodia camohorata. Cancer. Lett., 231(2): 215-27.

20.Gupta, SC., Kim, JH., Prasad, S. and Aggarwal, BB. (2010). Regulation of survival, proliferation, invasion, angiogenesis, and metastasis of tumor cells through modulation of inflammatory pathways by nutraceuticals, Cancer Metastasis Rev., 29: 405-434.

21.Agarwal, N., Majee, C. and Chakraborthy, GS. (2012). Natural herbs as anticancer drugs. Int. J. Pharam. Tech. Res., 4(3): 1142-1153.

22.Gopinath, P., Vadivel, SD., Kamatchiammal, S. and Saroja, V. (2013). Anticancerous activity of Albizia amara (Roxb.) Bovin using human breast cancer cells (MCF-7) by in vitro methods. Int. J. Pharma. Res. Rev., 2(8): 23-32.

23.Garcia Sancho, LEG., Yahia, EM., Garcia-Solis, P. and Gonzalez-Aguilar, GA. (2014). Inhibition of proliferation of breast cancer cells MCF-7 and MDA-MB-231 by lipophilic extracts of Papaya (Carica papaya L. var. Maradol) Fruit. Food. Nutr. Sci., 5: 2097-2103.

24.Kalla, PK., Chitti, S., Aghamirzaei, ST., Senthilkumar, R. and Selvam, A. (2014). Anticancer activity ossilymarin on MCF-7 and NCIH-23 cell lines. Ad. J. Bio. Res., 8(2): 57-61.

25.Graidist, P., Martla, M. and Sukpondma, Y. (2015). Cytotoxic activity of piper extracts in breast cancer cell lines. Nutrients., 7: 2707-2718.

26.Serasanambati, M., Chilakapati, SR., Manikonda, PK. and Kanala, JR. (2015). Anticancer activity of methanolic extract of berberis in MCF-7 human breast cancer cell lines. Int. J. Life Sci. Biotech. Pharma. Res., 4(1): 443-461.

27.Venkateswarlu, G., Rani Swarupa, M., Vani, PA. and Vineela, J. (2015). In vitro anticancer activity of petroleum ether extract of Cynodon dactylon. J. Pharma. Phytochem., 4(1): 164-168.

28.Arora, R., Agarwal, P., Ray, S., Singh, AK., Singh, VJ., Tyagi, AK. and Kapoor, S. (2007). MADS-box gene family in rice genome-wide identification, organization and expression profiling during reproductive development and stress. BMC Genomics., 8: 242(1-21).

29.Goktepe, M. and Ahmedna, L. (2012). Maness In vitro cancer research on ancient herbal remedies: A changing trend. J. App. Pharma. sci., 2(8):13-20.

30.Rekha, S. and Bhaskar, M. (2013). In vitro screening and identification of antioxidant activities of orange (Citrus sinesis) peel extract in different solvents. Int. J. pharm. Bio. Sci., 4(4): 405-412.

31.Adnan, M., Umer, A., Ahamed, I., Hayat, K. and Shakeel, NS. (2014). In vitro evalution of biological activities of citrus leaf extracts. Sains Malaysiana., 43(2):185-194.

32.Parashar, S., Sharma, H. and Garg, M. (2014). Antimicrobial and antioxidant activities of fruit and vegetable peels: A review. J. Pharmacol. Phytochem., 3(1): 160-164.

33.Safarzadeh, E., Shotorbani, SS. and Baradaran, B. (2014). Herbal medicine as inducers of apoptosis in cancer treatment. Adv. Pharm. Bull., 4(1): 421-427.

34.Singh, S. and Singh, R. (2014). Herbal medicine treatment of malaria in aliero local government area, kebbi, Nigeria. J. M. Plants Stu., 2(2): 117-126.

35.Mehra, S., Shukla, S., Srivastava, R., Mathew, J. and Mehra, M. (2015). Evalution of antimicrobial activity of peel and pulp extracts of C. paradise, C.medica and Limon against B. Cereus and M. Luteus. Australian. J. Basic. Applied. Sci., 9(1): 174-182.

36.Rosangkima, G. and Prasad, SB. (2004). Antitumour activity of some plants from Meghalaya and Mizoram against murine ascites Dolton's lymphoma. Indian J. Exp. Biol., 42: 981-988.

37.Chong, FW., Srikumar, C., Nagaraja, HS., Thanikachalam, PM. and Nagarajah, L. (2009). Expression of transforming growth factor- $\beta$ and determination of Apoptotic Index in histo pathological sections for assessment of the effects of Apigenin (4',5',7'-trihydroxyflavone) on Cyclosporine A induced renal damage. Malaysian J. Path., 31(1): 35-43.

38.Al-anbari, AK., Alkhesraji, T., Al-Mashhadani, A. and Aljewari, H. (2013). Determination of some chemical compounds in Citrus species in Iraq. Int. J. Ad. Res., 1(7): 555-562.

39.Duyn, MA. and Pivonka, E. (2000). Overview of the health benefits of fruits and vegetable consumption for the dietetics professional. J. Amer. Diet Association., 100(2): 1511-1521.

40.Dhanavade, MJ., Jalkute, CB., Ghosh, JS. and Sonawane, KD. (2011). Study Antimicrobial Activity of Lemon (Citrus lemon L.) Peel Extract. British. J. Pharmacol. Toxicol., 2(3): 119-122. 
41.Sawalha, SMS., Arraez-Roman, D., Segura-Carretero, A. and Fenandez-Gutierrez, A. (2009). Quantification of main phenolic compounds in sweet and bitter orange peel using CEMS/MS. Food. Chem., 116: 567-574.

42.Singh, S. and Rajam, MV. (2009). Citrus biotechnology: Achievements, limitations and future directions. Physio. Mol. Bio. Plants., 15(1): 3-22.

43.Ladaniya, MS. (2008). Citrus Fruit: Biology, technology and evaluation. Int. J. Phama. Sci., 12: 634-642.

44.Carina, LA., Ingrid, WL., Isabelle, CD., Tonia, VSL., Adeliana, SO., Maria, RAM., Edda, LL. and Mauricio, PS. (2004). Biological activity of proteins from pulps of tropical fruits. Food Chem., 85: 107-110.

45.Kokate, CK. (1988). Practical pharmacognosy, 2nd edition, Vallabh prakashan publishers, New Delhi., 4-29.

46.Mosmann T (1983). Rapid colorimetric assay for cellular growth and survival: application to proliferation and cytotoxicity assays. J.Immunol.Methods, 65: 55-63.

47.Yawata, A. (1998). Prolonged cell survival enhances peritoneal dissemination of gastric cancer cells. Oncogene., 16: $2681-6$.

48.Merina, N., Chandra, KJ. and Jibon, K. (2012). Medicinal plants with anticancer activities: A rev., 3(6): 22308407.

49.Larkin, T. (1983). Herbs are often more toxic than magical. FDA. Consum., 17: 4-11.

50.Saxe, TG. (1987). Toxicity of medicinal herbal preparations. Am. Fam. Physician., 35: 135-42.

51.Mishra, LC., Singh, BB. and Dagenais, S. (2000). Basis for the Therapeutic use of Withania somnifera (Ashwagandha): A Review. Alter. Medi. Rev., 5(4): 334-336.

52.Zhang, YJ., Abe, T., Tanaka, T., Yang, CR. and Kouno, I. (2001). Phyllan emblinins A-F, new Ellagitannins from Phyllanthus emblica. J. Nat. Prod., 64: 1527-1532.

53.Cragg, GM. and Newman, DJ. (2005). plants as a source of anticancer agents. J. Ethnopatho., 100: 72-79.

54.Kumar, VL. and Arya, S. (2006). Medicinal uses and pharmacological properties of Calotropis procera. In recent progress in medicinal plants., 11: 378-388.

55.Ahamed-Belkacem, A., Macalou, S., Borrelli, F., Capasso, R., Fattorusso, E. and Taglialatela-Scafati, O. (2007). Nonprenylated rotenoids, a new class of potent breast cancer resistance protein inhibitors. J. Med. Chem., 50(8): 1933-1938.

56.Norikura, T., Kojima-Yuasa, A., Shimizu, M., Huang, X., Xu, S. and Kametani, S. (2008). Mechanism of growth inhibitory effect of Blumea Balsamifera extract in Hepatocellular Carcinoma. Biosci. Biotech. Biochem., 72(5): 1183-1189.

57.Kundusen, S., Gupta, M., Mazumder, UK., Haldar, PK., Saha, P. and Bala, A. (2011). Antitumor activity of Citrus maxima (burm.) Merr. leaves in ehrlichs ascites carcinoma cell-treated mice. ISRN. Parmacol., 2: 1-8.

58.Nair, S. and Varalakshmi, KN. (2011). Anticancer, cytotoxic potential of Morninga olifera extracts on HeLa cell lines. J. Natur. Pharm., 2(3): 138-142.

59.Seawan, N., Koysomboon, S. and Chantrapromma, K. (2011). Anti-trypsinase and anticancer activities of flavonoids from Blumea Balsamifera Dc. J. Med. Plants. Res., 5(6): 1018-1025.

60.Hashim, MN., Rahmari, M., Cheng Lian, EG., Sukari, MA. and Yahayu, M. (2012). Antiproliferative Activity of Xanthones isolated from Artocarpus obtusus. Journal of biomedicine and Biotechnology. 02: 681-685.

61.Prabhu, D., Arulvasu, C., Babu, G., Manikandan, R. and Srinivasan, P. (2013). Biologically synthesized green silver nanoparticles from leaf extract of Vitex negundo L. induce growth-inhibitory effect on human colon canver cell line HCT15. Process Biochem., 48: 317-324.

62.Ashok, K. and Sivakumari, K. (2015). In silico docking of fucoidan compound against the selective proteins of HepG-2 cell line. Int. J. Chem. Pharm. Sci., 6(4): 976-979.

63.Manimaran, M., Sivakumari, K. and Ashok, K. (2015). Molecular studies of reservatrol against the human oral cancer cell line proteins (KB cells). Int. J. curr. Adv. Res., 4: 2319-2325.

64.Muthukala, B., Sivakumari, K. and Ashok, K. (2015). In silico docking of quercetin compound against the hela cell line proteins. Int. J. Curr. Pharm. Res., 7(1): 0975-0980.

65.Manimekalai, I., Sivakumari, K., Ashok, K. and Rajesh, S. (2016). Phytochemical profiling of mangosteen fruit, Garcinia mangostana. World. J. Pharm. Sci., 5(2): 221-252.

66.Manimekalai, I., Sivakumari, K., Ashok, K. and Rajesh, S. (2016). Antioxidant and anticancer potential of mangosteen fruit, Garinia mangostana against hepatocellular carcinoma (HepG-2) cell line. World. J. Pharm. Sci., 5(2): 253-293. 
67.Rajesh, S., Sivakumari, K., Ashok, K. and Abitha, AR. (2016). Anticancer activity of Cardiospermum helicacacabum leaf extracts against hepatocellular carcinoma cell line (HepG-2). World. J. Pharm. Sci., 5(3): 1133-1154.

68. Waterman, PG. and Grundon, MF. (1983). Chemistry and chemical taxonomy of the rutales. Academic. Press. Inc., NewYork.

69.Mohanapriya, M., Ramaswamy, L. and Rajendren, R. (2013). Health and medicinal properties of lemon (Citrus Limonum). Int. J. Ayur. Herb. Med., 3(1): 1095-1100.

70.Kegley, SE., Hill, BR., Orme, S. and Choi, AH. (2005). Limonene pan pesticide database. Ind. Chem., 8(1): 572578.

71. Chede, PS. (2013). Phytochemical analysis of citrus sinesis peel. Int. J. Pharm. Bio. Sci., 4(1): 339-343.

72.Burt, SA. (2004). Essential oils: their antibacterial properties and potential applications in foods: A review, Int. J. Food. Microbial., 24: 223-253.

73.Ortuno, A., Gomez, P., Baidez, A., Frias, V. and Del Rio, JA. (2006). Citrus sp: a source of flavonoids of pharmaceutical interest potential health benefits of Citrus. ACS Symp. Ser., 936: 175-185.

74.Strange, RR., Miland, SL., Eckert, JW. and Sims, JJ. (1993). An antifungal compound produced by grapefruit and valencia orange after wounding of the peel, J. Nat. Prod., 56: 1627-1629.

75.Crowell, PL. (1999). Prevention and therapy of cancer by dietary monoterpenes. The J. Nutr., 129(3): 775S-778S.

76.Tsuda, H., Ohshima, Y. and Nomoto, H. (2004). Cancer prevention by natural compound. Drug Metab. Pharm., 19(4): 245-63.

77.Shahnah, SM., Ali, S., Ansari, H. and Bagri, P. (2007). New sequiterpene derivative from fruit peel of Citrus limon (Linn) Burn. Food Sci. Pharm., 75: 165-170.

78.Ahmad, MM., Salim-ur-Rehman, Z., Iqbal, FM., Anjum, N. and Sultan JI. (2006). Genetic variability to essential oil composition in four citrus fruit species. Pak. J. Bot., 38(2): 319-324.

79.Aronson, JK. (2001). Nature Publishing Group. Retrieved from: http://medicine.nature.com.

80.Ighodaro, O. (2012). Evaluation study on Nigerian species of Musa paradisiaca peels: phytochemical screening, proximate analysis, mineral composition and antimicrobial activities. Res., 4: 17-20.

81.El Zawawy, AN. (2015). Antioxidant, antitumor, antimicrobial studies and quantitative phytochemical estimation of ethanolic extracts of selected fruit peels. Int. J. Curr. Microbiol. App. Sci., 4(5): 298-309.

82.Hashemi, M., Karami-Tehrani, F. and Ghavami, S. (2004). Cytotoxicity effect of Cladribine on the MCF-7 Human breast cancer cell line. Iran. Biomed. J., 8(1): 7-12.

83.Yang, HL., Chen, CS., Chang, WH., Lu, FJ., Lai, YC. and Chen, CC. (2006). Growth inhibition and induction of apoptosis in MCF-7 Breast cancer cells by Antodia camohorata. Cancer. Lett., 231(2): 215-27.

84.Khalil, AM. (2009). Inhibition of the vitro growth of human mammary carcinoma cell line (MCF-7) by selenium and vitamin E. J. Bio. Sci., 2: 37-46.

85.Ibrahim, T., Mercatali, L., Sacanna, E., Tesei, A., Carloni, S., Ulivi, P., Liverani, C., Fabbri, F., Zanoni, M., Zoli, W. and Dino, A. (2012). Inhibition of breast cancer cell proliferation in repeated and non-repeated treatment with Zoledronic acid. Cancer Cell Int., 12: 48(12).

86.AbuHammad, S. and Zihlif, M. (2013). Gene expression alterations in doxorubicin resistant MCF7 breast cancer cell line. Genomics., 101: 213-220.

87.Sadowska, A., Prokopiuk, S., Miltyk, W., Surazynski, A., Konoczuk, J., Sawicka, D. and Car, H. (2013). Metronidazole affects breast cancer cell lines. Anticancer drugs., 58(1): 90-95.

88.Wu, S., Guo, J., Wei, W., Zhang, J., Fang, J. and Beebe, JS. (2014). Enhanced breast cancer therapy with nsPEFs and low concentrations of gemcitabine. Cancer Res., 14: 98.

89.Swapana, M. and Padamavathy, C. (2015). A critical review on breast cancer literature: screening awareness and preventive measures. Mediterranean. J. Soc. Sci., 6(4): 2039-2117. 